\title{
Bartłomiej SECLER
}

Poznań

\section{Spór o multipleks. Telewizja Trwam kontra Krajowa Rada Radiofonii i Telewizji}

\section{Wprowadzenie}

D roces cyfryzacji naziemnej telewizji w Polsce jest jednym z największych i najważniejszych projektów w sferze publicznej, polegający na zastąpieniu tradycyjnej techniki nadawania analogowego nowoczesną techniką cyfrową. Niewątpliwie wdrożenie naziemnej telewizji cyfrowej jest istotnym zwrotem technologicznym łączącym zagadnienia społeczne, ekonomiczne i techniczne. Zwrot ten przyczyni się m.in. do zaoferowania odbiorcom bogatej oferty programowej, poprawie jakości dźwięku i obrazu czy dostępu do wielu usług dodatkowych, np. tych o charakterze interaktywnym ${ }^{1}$. Cyfryzacja przyczyni się również do wzrostu konkurencyjności wśród nadawców telewizyjnych oraz pluralistycznej oferty programowej. Jak zauważa Jędrzej Skrzypczak, zaletą cyfryzacji będzie możliwość korzystania z e-edukacji, e-administracji publicznej, łatwiejszy dostęp do informacji publicznej, czego konsekwencją może być większe zaangażowanie obywateli w proces demokratyzacji państwa, a także urzeczywistnianie idei społeczeństwa informacyjnego. Oczywiście twierdzenie, że czynnikiem [...] zmian społecznych jest tylko nowa technologia, byłoby zbyt dużym uproszczeniem. Trzeba bowiem brać pod uwage także procesy polityczne, socjoekonomiczne i kulturowe. Z pewnościa jest to jednak $w$ ostatnich dekadach element niezwykle istotny, skutkujacy mnogościa zmian również $w$ sferze polityki, socjologii, ekonomii i kultury ${ }^{2}$ - argumentuje badacz.

Rozpowszechnianie programu w sposób cyfrowy możliwe jest poprzez trzy uruchomione dotąd multipleksy ${ }^{3}$. Zgodnie z ustawą o wdrożeniu naziemnej telewizji cyfrowej ${ }^{4}$ multipleks trzeci - MUX-3 został przeznaczony w całości dla Telewizji Polskiej (TVP) ${ }^{5}$. Drugi multi-

\footnotetext{
${ }^{1}$ Por. Proces cyfryzacji, http://www.cyfryzacja.gov.pl/Proces,cyfryzacji,8.html, 3.01.2013.

2 J. Skrzypczak, Polityka medialna w okresie konwersji cyfrowej radiofonii i telewizji, Poznań 2011, s. 30.

${ }^{3}$ Art. 2 pkt 20a ustawy z dnia 16 lipca 2004 r. - Prawo telekomunikacyjne (Dz. U. z 2004 Nr 171, poz. 1800 z późn. zm.) definiuje multipleks jako zespolony strumień danych cyfrowych, składajacych się z dwóch lub więcej strumieni utworzonych $z$ danych wchodzacych $w$ skład treści programów radiofonicznych lub telewizyjnych, oraz danych dodatkowych, obejmujących w szczególności dane zwiqzane z systemem dostępu warunkowego lub ustugami dodatkowymi. Z kolei na stronie internetowej poświęconej cyfryzacji czytamy: Multipleks to, nadawana w pojedynczym kanale telewizyjnym, ,paczka cyfrowa” składajaca się z programów telewizyjnych i radiofonicznych oraz dodatkowych informacji w postaci cyfrowej (np. elektronicznego przewodnika po programach, tzw. EPG). Nie wszystkie wymienione składowe multipleksu musza w nim występować jednocześnie. W obecnie nadawanych multipleksach MUX-1, MUX-2 i MUX-3 nie sq np. obecne programy radiofoniczne. Za: Multipleksy, http://cyfryzacja.gov.pl/Multipleksy,245.html, 3.01.2013.

${ }^{4}$ Ustawa z dnia 30 czerwca 2011 r. o wdrożeniu naziemnej telewizji cyfrowej (Dz. U. z 2011 Nr 153, poz. 903).

${ }^{5}$ Zgodnie z komunikatem prasowym Krajowej Rady Radiofonii i Telewizji z 21 kwietnia 2012 r. budowa MUX-3 będzie mogła być dokończona [...] po wyłaczeniu nadawania analogowego. Dlatego też programy TVP umieszone sq czasowo na MUX-1, który będq musiały opuścić najdalej 27 kwietnia 2014 roku. Komunikat prasowy
} 
pleks - MUX-2 jest dla dotychczasowych ogólnopolskich nadawców komercyjnych rozpowszechniających dotąd swój program w naziemnym systemie analogowym. Chodzi w tym przypadku o Polsat, TVN, Puls i TV4 ${ }^{6}$ - nadawcy ci otrzymali po dwa miejsca na MUX-2 ${ }^{7}$. Natomiast multipleks pierwszy - MUX-1 przeznaczony został dla nowych nadawców, którzy nie rozpowszechniali dotąd sygnału w naziemnym systemie analogowym. Zwolnione przez TVP miejsca zastąpią programy wybrane w konkursie ogłoszonym przez Krajową Radę Radiofonii i Telewizji (KRRiT). Cztery inne miejsca na MUX-1 KRRiT rozdysponowała w konkursie zakończonym w kwietniu 2011 r. Miejsca na multipleksie otrzymały wówczas: Kino Polska TV, Eska TV, ATM Grupa i Stavka. Trzy miesiące później spółka Kino Polska TV zrezygnowała z koncesji na nadawanie, zaś KRRiT zdecydowała, że na zwolnionym miejscu znajdzie się program z polską muzyką Polo TV.

W konkursie w 2011 r. brała także udział Telewizja Trwam (TV Trwam), której właścicielem jest Fundacja Lux Veritatis. KRRiT odmówiła wówczas miejsca na MUX-1 telewizji kojarzonej z o. Tadeuszem Rydzykiem. Nadawca uznał decyzję Rady za bezpodstawną. Tym samym rozpoczął się trwający wiele miesięcy konflikt pomiędzy TV Trwam a KRRiT. Szybko pojawiły się także zarzuty o dyskryminację nadawcy katolickiego, a tym samym lekceważenie polskich katolików. W spór pomiędzy telewizją a Radą zaangażowało się wiele środowisk i osób - od zwolenników mediów związanych z o. T. Rydzykiem, przez dziennikarzy i publicystów, po polityków i hierarchów Kościoła katolickiego w Polsce.

Celem niniejszego artykułu jest przede wszystkim rekonstrukcja wspomnianego sporu - ukazania jego tła oraz argumentów każdej ze stron. Jako że w chwili ukończenia tekstu (luty 2013 r.) konflikt nie znalazł rozstrzygnięcia, chciałbym zwrócić także uwagę - w podsumowaniu - na możliwe scenariusze zakończenia sporu i płynące z niego wnioski na przyszłość.

\section{Lux Veritatis i Telewizja Trwam}

Fundacja Lux Veritatis ${ }^{8}$ została założona w 1998 r. przez ojców redemptorystów: Jana Króla i Tadeusza Rydzyka. Działalność statutowa tego podmiotu sprowadza się przede wszystkim do wspierania Kościoła katolickiego w głoszeniu Dobrej Nowiny, w tym w szczególności przez: propagowanie zasad moralnych opartych na Dekalogu w środkach społecznej komunikacji, krzewienie w społeczeństwie kultury polskiej zwiazanej z chrześcijaństwem, integrowanie środowisk naukowych, twórczych i dziennikarskich $w$ duchu wartości chrześcijańskich ${ }^{9}$. Fundacja znana jest $\mathrm{z}$ wielu rozmaitych przedsięwzięc ${ }^{10}$, z których najważniejszym było uruchomienie TV Trwam i uzyskanie w 2003 r. koncesji na nadawanie programu drogą

MUX-1 i cyfryzacja telewizji w Polsce, http://www.krrit.gov.pl/dla-mediow-i-analitykow/aktualnosci/news,648, mux-1-i-cyfryzacja-telewizji-w-polsce--konferencja-prasowa-krrit.html, 3.01.2013.

${ }^{6}$ Por. ibidem.

${ }^{7}$ Na MUX-2 są dostępne - Polsat, Polsat Sport News, TVN, TVN7, TV Puls, TV Puls 2, TV4, TV6.

${ }^{8} \mathrm{Z}$ języka łacińskiego ,światło prawdy".

${ }^{9}$ Fundacja Lux Veritatis, http://www.luxveritatis.pl/index.php?strona=o-fundacji, 5.01.2013.

${ }^{10}$ W 2006 roku Fundacja uzyskała w drodze uchwały Zarządu Narodowego Funduszu Ochrony Środowiska i Gospodarki Wodnej dotację na realizację projektu Prace geologiczne dla poszukiwania i wstęnego ustalenia zasobów eksploatacyjnych wód termalnych z utworów wapienia muszlowego lub liasu w Toruniu wraz z określeniem warunków hydrogeologicznych $w$ zwiazku z wtłaczaniem wód do górotworu w interwale utworów wapienia muszlowego lub liasu w Toruniu - otwór TG1. Zob. informację w tej sprawie http://www.nfosigw.gov.pl/gfx/nfosigw/userfiles/files/o_nfosigw/mity_i_fakty/lux_veritatis_nfosigw_informacje_o_umowie.pdf, 5.01.2013. Inwestycja w postaci geotermalnej zakończyła się powodzeniem. 
satelitarną ${ }^{11}$. Program TV Trwam adresowany jest przede wszystkim do polskich odbiorców oraz środowisk polonijnych żyjących i działających w różnych częściach świata. Na swojej stronie internetowej Lux Veritatis informuje, że program TV Trwam od samego poczatku zyskat szerokie uznanie, wyróżniajac się na tle innych programów telewizyjnych oryginalna zawartościa merytoryczna, konstrukcja ramówki, jak również interaktywna forma audycji, bardzo często emitowanych na żywo ${ }^{12}$. Trzeba przyznać, że telewizja posiada bardzo bogaty program, w którym znajdują się serwisy informacyjne, audycje dla dzieci i młodzieży, audycje publicystyczne czy sztandarowe „Rozmowy Niedokończone” nadawane również w Radiu Maryja ${ }^{13}$. W minionych latach telewizja związana z o. T. Rydzykiem (podobnie jak wspomniane Radio Maryja) była przedmiotem krytyki - jednak nie za programy o treści religijnej, a te o charakterze publicystycznym czy politycznym. Wiele kontrowersji wywołało także wydarzenie związane z podpisaniem w 2006 r. tzw. paktu stabilizacyjnego pomiędzy Prawem i Sprawiedliwością, Samoobroną i Ligą Polskich Rodzin. Zawiązanie porozumienia odbyło się tylko w obecności dziennikarzy Radia Maryja, TV Trwam i „Naszego Dziennika”. Co ciekawe, Kościół, który wobec wspomnianych mediów przejawia postawę dość zachowawczą, w tym przypadku zareagował niemal błyskawicznie, krytykując zaistniałą sytuację. Rzecznik Konferencji Episkopatu Polski ks. Józef Kloch wydał komunikat, w którym padły następujące słowa: W zwiazku ze znanymi wydarzeniami, jakie miały miejsce podczas spotkań $z$ dziennikarzami przy okazji zawarcia paktu stabilizacyjnego, informuje się, że uczestniczace w nich media wiqzane z Kościołem nie działały w jego imieniu. Poczynania te nie byty konsultowane z żadnym gremium statutowym Konferencji Episkopatu Polski [...]. Konferencja Episkopatu Polski zawsze opowiadała się za jednakowym dostępem wszystkich mediów do informacji dotyczacych życia publicznego. Wobec zaistniatej sytuacji raz jeszcze prosi wszystkich polityków działajacych z mandatu społecznego, o solidarna wspótpracę w trosce o Polske $i$ jej obywateli, przedkładajac dobro wspólne nad interesy osobiste i partyjne ${ }^{14}$.

Kilka dni później abp Józef Michalik, abp Stanisław Gądecki i bp Piotr Libera wystosowali pismo do o. Zdzisława Klafki przełożonego zakonu redemptorystów: W zwiazku z sytuacja zaistniała dnia 2 lutego br., w której obecność Radia Maryja i Telewizji Trwam w dokonujacych się atakach politycznych w Parlamencie sprawiła, że Kościót jest postrzegany jako strona popierajaca jednoznacznie jedna partie politycznq. Prezydium Episkopatu Polski poczuwa się w obowiazku upomnieć Ojca Prowincjała, który jest odpowiedzialny za zaangażowanie Ojców prowadzacych powyższe media ${ }^{15}$. Hierarchowie przypomnieli również, że media katolickie nie mogą zostać zinstrumentalizowane przez jakąkolwiek opcję polityczną i zaapelowali do prowincjała redemptorystów, by zadbał o respektowanie przez Radio Maryja i Telewizję Trwam wskazań katolickiej nauki społecznej ${ }^{16}$.

Warto podkreślić, że zwolennicy Radia Maryja i TV Trwam uważają te środki przekazu za niezależne i wolne. Zygmunt Zieliński w jednej ze swoich książek pisze: [...] mediom katolic-

\footnotetext{
${ }^{11}$ Koncesja została przyznana przez KRRiT na 10 lat. W 2012 r. Rada przedłużyła TV Trwam koncesję do 2023 r. Zob. komunikat prasowy KRRiT, KRRiT podjęła uchwate o udzieleniu koncesji dla Telewizji Trwam, http://www.krrit.gov.pl/dla-mediow-i-analitykow/aktualnosci/news, 730,krrit-podjela-uchwale-o-udzieleniu-koncesji-dla-telewizji-trwam.html, 5.01.2013.

12 Por. Fundacja Lux Veritatis, http://www.luxveritatis.pl/index.php?strona=o-fundacji, 5.01.2013.

${ }^{13}$ B. Secler, Dwie dekady katolickich środków spolecznego przekazu w Polsce (1989-2009), w: Media dawne $i$ współczesne, red. B. Kosmanowa, t. V, Poznań 2010, s. 83.

${ }_{14}$ Za: Komunikat Biura Prasowego Konferencji Episkopatu Polski, Warszawa, 4.02.2006.

${ }^{15}$ K. Wiśniewska, M. Kopiński, J. Hołub, Już dość Rydzyka, „Gazeta Wyborcza” z dnia 16 lutego 2006 r.

${ }^{16}$ Ibidem.
} 
kim w kraju rzqdzonym przez środowiska liberalne przetrwać nie jest łatwo. [...] Być może takiej nagonki, na wszystko to, co nie mieści się w wyznaczonym schemacie, nie byłoby, gdyby media były w polskich rękach. Wówczas Zachód nie mógłby narzucać własnych pogląów. $Z$ kolei $w$ takim środowisku medialnym nie ma miejsca na niezależne medium, a takim niewatpliwie jest chociażby Radio Maryja czy Telewizja Trwam $^{17}$. W moim przekonaniu pogląd ten jest jednak bardzo dyskusyjny ${ }^{18}$.

\section{Kontrowersje wokół procesu koncesyjnego}

W marcu 2011 r. przewodniczący KRRiT Jan Dworak podał do publicznej wiadomości listę 17 wnioskodawców ubiegających się o rozszerzenie koncesji na rozpowszechnianie programu w sposób rozsiewczy satelitarny, o charakterze określonym w udzielonych koncesjach, polegającym na przyznaniu prawa do rozpowszechniania programu drogą rozsiewczą naziemną w sposób cyfrowy w sygnale multipleksu pierwszego ${ }^{19}$. Wykaz obejmował wnioski złożone do dnia 4 marca 2011 r. (tabela 1).

Tabela 1

Podmioty ubiegające się miejsce na multipleksie pierwszym

\begin{tabular}{|r|l|l|l||}
\hline \multicolumn{1}{|c|}{ Lp. } & \multicolumn{1}{|c|}{ Wnioskodawca } & \multicolumn{1}{c||}{ Siedziba } & \multicolumn{1}{|c||}{ Nazwa programu } \\
\hline 1 & 4fun Media S.A. & Warszawa & Warszawa \\
\hline 2 & ASTRO S.A. & Bielany Wrocławskie & ATM ROZRYWKA TV \\
\hline 3 & ATM GRUPA S.A. & Warszawa & CTV \\
\hline 4 & Cable Television Networks \&Partners Sp. z o.o. & Warszawa & ESKA TV \\
\hline 5 & ESKA TV S.A. & Warszawa & TRWAM \\
\hline 6 & Fundacja LUX VERITATIS & Warszawa & Kino Polska Nostalgia \\
\hline 7 & KINO POLSKA TV S.A. & Warszawa & Polo TV \\
\hline 8 & Lemon Records Sp. z o.o. & Warszawa & Tele 5 \\
\hline 9 & MEDIASAT Sp. z.o.o. & Kraków & RMF TV \\
\hline 10 & MULTIMEDIA Sp. z o.o. & Warszawa & Polskie Radio Czwórka \\
\hline 11 & POLSKIE RADIO S.A. & Warszawa & U-TV \\
\hline 12 & STAVKA Sp. z o.o. & Warszawa & SUPERSTACJA \\
\hline 13 & SUPERSTACJA Sp. z o.o. & Warszawa & Orange Sport Info \\
\hline 14 & Telekomunikacja Polska S.A. & Warszawa & iTV \\
\hline 15 & TELESTAR S.A. & Warszawa & MACHINA TV \\
\hline 16 & TV POINT GROUP S.A. & Warszawa & TVN Meteo \\
\hline 17 & TVN S.A. & & \\
\hline \hline
\end{tabular}

Źródło: Ogłoszenie dot. listy wnioskodawców, którzy złożyli wnioski o rozszerzenie koncesji na rozpowszechnianie programu telewizyjnego, http://www.krrit.gov.pl/Data/Files/_public/Portals/0/koncesje/ogloszenia/ogloszenia_mp/ lw_110314_mux_1.pdf, 10.01.2013.

${ }^{17}$ Z. Zieliński, Kościót w Polsce 1944-2007, Wydawnictwo Poznańskie, Poznań 2009, s. 384.

${ }^{18}$ Szerzej: B. Secler, Wolność katolickich środków społecznego przekazu. Rzeczywistość czy fikcja?, w: Media dawne $i$ współczesne, red. B. Kosmanowa, t. III, Wydawnictwo Naukowe WNPiD UAM, Poznań 2008.

${ }^{19}$ Por. http://www.krrit.gov.pl/Data/Files/_public/Portals/0/koncesje/ogloszenia/ogloszenia_mp/lw_110314_mux_1.pdf, 10.01.2013. 
Jednym z wnioskodawców była Fundacja Lux Veritatis ubiegająca się o miejsce na MUX-1 dla Telewizji Trwam. Opierając się na kryteriach określonych w ustawie o radiofonii i telewizji oraz rozporządzeniu regulującym postępowanie koncesyjne, KRRiT uchwałami z dnia 26 kwietnia 2011 r. i 6 lipca 2011 r. przyznała miejsce na multipleksie pierwszym czterem podmiotom, o których pisałem już we wstępie niniejszego tekstu. W kwietniowej uchwale Rada zwróciła uwagę, iż dokonując wyboru chciała przede wszystkim zapewnić odbiorcom różnorodną ofertę programową, w której obok obecnych już programów Telewizji Polskiej (TVP 1, TVP 2, TVP Info) znajdą się: kanał filmowy (Kino Polska Nostalgia), muzyczny (Eska TV), rozrywkowy (ATM Rozrywka TV), informacyjno-publicystyczno-poradnikowy (U-TV). Warto podkreślić, że Rada podejmując decyzję wzięła także pod uwagę to, iż wybrane podmioty należą do grona nowych nadawców na rynku telewizyjnym o dobrej kondycji finansowej umożliwiającej realizację niezbędnych inwestycji ${ }^{20}$.

Decyzja przewodniczącego KRRiT w sprawie miejsca na multipleksie pierwszym została wydana 29 lipca $2011 \mathrm{r}$. W uzasadnieniu czytamy: W toku postępowania o udzielenie koncesji oceniano w szczególności stopień zgodności zamierzonej działalności programowej z zadaniami określonymi w art. 1 ust. 1 ustawy o radiofonii i telewizji, z uwzględnieniem stopnia realizacji tych zadań przez innych nadawców działajacych na obszarze objętym koncesja, możliwość dokonania przez wnioskodawce koniecznych inwestycji i finansowania programu, przewidywany udziat w programie audycji wytworzonych przez nadawcę lub na jego zamówienie albo we współdziałaniu z innymi nadawcami, przewidywany udział audycji wytworzonych pierwotnie w język polskim oraz audycji europejskich, dotychczasowe przestrzeganie przepisów dotyczqcych radiokomunikacji i środków masowego przekazu. Ponadto oceniano, które programy będa realizować, zgodnie z art. 6 ustawy o radiofonii i telewizji zasadę otwartego i pluralistycznego charakteru radiofonii i telewizji, rozumiana jako pluralizm źródet informowania ${ }^{21}$. W uzasadnieniu wniosku w części poświęconej Fundacji Lux Veritatis Rada stwierdza, że przedstawione przez fundację założenia finansowe nie gwarantują realizacji przedsięwzięcia. Obszerne fragmenty dotyczące tej właśnie kwestii nie zostały udostępnione. W tekście uzasadnienia znajduje się informacja następującej treści: Treść nie podlega udostępnieniu na podstawie art. 5 ust. 2 ustawy z dnia 6 września 2001 r. o dostępie do informacji publicznej (Dz. U. Nr 112, poz. 1198 z późn. zm.), tj. ze względu na ochronę tajemnicy przedsiębiorcy zastrzeżona przez Fundację Lux Veritatis ${ }^{22}$.

Do KRRiT wpłynęły cztery odwołania od wnioskodawców, którzy nie otrzymali koncesji. Oprócz Fundacji Lux Veritatis były to także spółki: Mediasat, Superstacja, Astro. Rada zwróciła uwagę, że każdy z wnioskodawców zaskarżył decyzję w innym zakresie, używając innych argumentów. Zaskarżenie ze strony Fundacji Lux Veritatis zostało wystosowane 24 sierpnia 2011 r. Jej pełnomocnik wskazując na rażącą dysproporcję pomiędzy traktowaniem nadawcy katolickiego a innych podmiotów, domagał się ponownego rozpatrzenia sprawy dotyczącej umieszczenia TV Trwam na multipleksie. Przedstawiciel funkcji zwrócił ponadto uwagę, iż przewodniczący KRRiT naruszył przepisy Kodeksu postępowania administracyjnego, co w konsekwencji przyczyniło się do błędnej oceny zgromadzonego w sprawie materiału dowodowego ${ }^{23}$. Przewod-

\footnotetext{
${ }^{20}$ Por. Krajowa Rada Radiofonii i Telewizji, http:/www.krrit.gov.pl/Data/Files/_public/pliki/radiofonia/ 110426_rozstrzygniecie_mux1.pdf, 10.01.2013.

${ }^{21}$ Przewodniczący Krajowej Rady Radiofonii i Telewizji, Decyzja Nr DK - 137/2011 z 29 lipca 2011 r.

${ }^{22}$ Ibidem.

23 J. Dytkowski, Złe rozdanie Dworaka, http://stary.naszdziennik.pl/index.php?dat=20110825\&typ=po\&id=po03.txt, 14.01.2013.
} 
niczący KRRiT raz jeszcze wyraziła pogląd, że odmowa umieszczenia TV Trwam na MUX-1 była podyktowana względami finansowymi, nie zaś dyskryminacją nadawcy katolickiego. o. T. Rydzyk w wypowiedzi dla „Naszego Dziennika” podkreślił, że działanie Rady jest wymierzone przeciwko pluralizmowi. Absolutnie takie postępowanie świadczy o nieuczciwości. Jest to zreszta działanie analogiczne do podejmowanego wobec Radia Maryja, którego celem jest doprowadzenie do zamknięcia tych medió $w^{24}$ - stwierdził redemptorysta. W tórowały mu środowiska i osoby związane z tymi mediami, m.in. Krystyna Czuba, która podkreślała, że Fundacja funkcjonuje ze składek i jeżeli społeczeństwo uzna, że telewizja jest potrzebna, to jej odbiorcy zrobia wszystko, by pokryć tego koszty i nie naraża nikogo na żadne kłopoty ${ }^{25}$. Warto jednak nadmienić, iż z ogólnodostępnych danych wynika, że majątek fundacji w końcu 2010 roku wynosił ponad $90 \mathrm{mln}$ złotych, zaś zadłużenie ponad $68 \mathrm{mln}$ zł. Odnotowywano także straty związane ze zmniejszającym się poziomem datków ${ }^{26}$.

Proces odwoławczy toczył się łącznie dla wszystkich skarżących. W komunikacie KRRiT podkreślono, że rada dokonała bardzo wnikliwiej i rzetelnej analizy wszystkich wniosków odwoławczych. Na tej podstawie została podjęta decyzja o podtrzymaniu w mocy decyzji z 29 lipca 2011 r. $^{27}$

O pozytywne rozpatrzenie przez KRRiT odwołania złożonego przez Lux Veritatis apelowały osoby prywatne, politycy, osoby duchowne. Głos zabrała także Rada Stała Konferencji Episkopatu Polski, która w wydanym oświadczeniu zaapelowała o przyznanie TV Trwam miejsca na multipleksie cyfrowym. Wykluczenie stacji o charakterze religijnym $w$ procesie koncesyjnym narusza zasadę pluralizmu oraz równości wobec prawa tym bardziej, że większość mieszkańców naszego kraju to katolicy, którzy powinni mieć zapewniony swobodny dostęp do programów TV Trwam w systemie naziemnej telewizji cyfrowej. Oczekuja tego równiez liczni odbiorcy, $w$ tym wielu chorych $i$ samotnych. Ufamy, że TV Trwam-nadajaca od ponad ośmiu lat $i$ wykazujaca stabilność finansowq-zostanie wtaczona do systemu telewizji cyfrowej $w$ Polsce ${ }^{28}$ - napisali biskupi.

W wielu kolejnych wypowiedziach przewodniczący Jan Dworak zwracał uwagę, że Fundacja Lux Veritatis nie przedstawiła stosownych dokumentów, które mogłyby świadczyć o zdolności sfinansowania nadawania programu na MUX-1. Nadto informował, że podmiot ubiegający się o koncesję odmówił udzielenie KRRiT informacji o pożyczce udzielonej przez Warszawską Prowincję Redemptorystów ${ }^{29}$. W jednym z wywiadów J. Dworak stwierdził, że nie ma żadnego spisku majacego na celu likwidację TV Trwam czy Radia Maryja, a decyzję nieprzyznania telewizji miejsca na multipleksie cyfrowym Rada podjęta sama, na własna odpowiedzialność $c^{30}$.

${ }^{24}$ Ibidem.

${ }^{25}$ Ibidem.

${ }^{26}$ Za: Wyrok Wojewódzkiego Sądu Administracyjnego w Warszawie z dnia 25 maja 2012 r., sygn. akt. VI $\mathrm{SA} / \mathrm{Wa} 627 / 12$.

${ }^{27}$ Komunikat prasowy, KRRiT utrzymała w mocy decyzję Przewodniczqcego z 29 lipca 2011 r. o rozszerzeniu koncesji na nadawanie satelitarne naziemne w sygnale multipleksu pierwszego, http://www.krrit.gov.pl/dla-mediow-i-analitykow/aktualnosci/news,576,krrit-utrzymala-w-mocy-decyzje-przewodniczacego-z-29-lipca-2011-r-o-rozszerzeniu-koncesji-na-nadawanie-satelitarne-naziemne-w-sygnale-multipleksu-pierwszego.html, 15.01.2013.

${ }^{28}$ Apel Rady Stalej KEP w sprawie TV Trwam, http://www.redemptor.pl/aktualnosci.php?id=339\&typ=1, 15.01.2013.

${ }^{29}$ Chodziło o pożyczkę na kwotę $68 \mathrm{mln}$ zł, zaś cały majątek fundacji - jak już zostało wskazane wyżej - to ok. 90 mln zł. Termin spłaty pożyczki mija w 2019 r., a zatem w czasie, na jaki KRRiT miałaby przyznać koncesję na nadawanie programu na MUX-1.

${ }^{30}$ Dworak: nie ma żadnego spisku, http://www.rp.pl/artykul/793961,864022-Dworak-nie-ma-spisku-majacego-na-celu-likwidacje-TV-Trwam.html, 15.01.2013. 
Dodał także: Podejmujac decyzję dotyczqca TV Trwam nie głosowaliśmy za Panem Bogiem, czy przeciwko Panu Bogu, i nie zgadzamy się z takim stawianiem sprawy, z fatszywym dzieleniem na tej podstawie polskiego społeczeństwa, w tym również osób, które zasiadaja w Krajowej Radzie, na osoby, które sq z Panem Bogiem i które sq przeciwko Panu Bogu. To jest zbyt daleko idace uproszczenie, które nie tylko uniemożliwia rozmowę na temat rzeczywistych problemów, ale jest krzywdzqce i nieprawdziwe ${ }^{31}$.

Koszty związane z budową multipleksu są szacowane na $600 \mathrm{mln}$ zł. W zawiązku z tak wysoką kwotą, obciążenie kosztami nadawania nadawcy jednego programu to koszt rzędu $7 \mathrm{mln}$ zł na okres przyznania koncesji, tj. 10 lat. Do tego dochodzą jeszcze koszty udzielenia tej koncesji - jest to kwota $12 \mathrm{mln} \mathrm{zt}^{32}$.

Podejrzenia o brak obiektywności KRRiT pojawiły się w jednym z tekstów na łamach dziennika „Rzeczpospolita”. Dziennikarze gazety, którzy dotarli do wniosków koncesyjnych złożonych w KRRiT, zwrócili uwagę, że Rada przyznała koncesje nadawcom, którzy generowali straty, mieli ujemne kapitały własne czy nie posiadali bazy emisyjnej. Finanse Fundacji Lux Veritatis, właściciela TV Trwam, która z powodu ,, braku wiarygodności finansowej” nie otrzymała miejsca na multipleksie cyfrowym, sq zdecydowanie lepsze od trzech innych nadawców posiadajacych koncesje $e^{33}$ - napisali autorzy tekstu. Nadto wykazali, że w 2010 r. Lux Veritatis wygenerowała zysk w kwocie 3,5 mln zł netto, zaś straty wykazały Stavka -4 tys. zł oraz Eska - niecałe 2,3 mln zł. Biorąc pod uwagę kapitał własny, właściciel TV Trwam umieścił we wniosku koncesyjnym prawie 20,5 mln kapitału własnego, podczas gdy Stavka wykazała 91 tys. zł, a Eska kapitał ujemny - 3,8 mln $\mathrm{zt}^{34}$.

Co ciekawe, że KRRiT - odrzucając wniosek ze względów finansowych - doceniła w postępowaniu koncesyjnym odrębność oferty programowej TV Trwam, przede wszystkim zasadniczy atut, jakim jest religijny aspekt programu. Kryterium to nie mogło być jednak uwzględnione z powodu wskazanych problemów finansowych. Przeciwnicy KRRiT odpierając te argumenty przez kolejne miesiące stali (i nadal stoją) na stanowisku, że za decyzją Rady kryje się chęć zniszczenia TV Trwam. Rozgorzała zatem - jak określała to prasa - ideologiczna wojna ${ }^{35}$. W tym kontekście Cezary Michalski napisał na łamach „Newsweek Polska”: Ojciec Tadeusz Rydzyk i żyjace w symbiozie z jego mediami dwa prawicowe ugrupowania - PiS i Solidarna Polska - mówiq o nowym totalitaryzmie, o prowadzeniu polityki antynarodowej, o trwajacych w Polsce prześladowaniach i dyskryminacji chrześcijan. Druga strona tej wojny udaje, że nawet nie jest stronq. Jan Dworak i inni członkowie Krajowej Rady Radiofonii i Telewizji ukryli się za obiektywnym, bezosobowym charakterem administracyjnych procedur. Jedynym przedstawionym przez nich argumentem jest brak wiarygodności finansowej fundacji Lux Veritatis o. Rydzyka, będacej wnioskodawca w procesie koncesyjnym ${ }^{36}$.

W kontekście decyzji KRRiT warto również zwrócić uwagę na raport przygotowany przez Nielsen Audience Measurement, metodologicznie oparty na badaniach telemetrycznych, z którego wynika m.in. że wyspecjalizowany program TV Trwam oglądało w okresie

\footnotetext{
${ }^{31}$ Ibidem.

${ }^{32}$ Ibidem.

${ }^{33}$ I. Kacprzak, K. Baranowska, W. Wybranowski, TV Trwam finansowo stoi lepiej niż inni nadawcy, http://www.rp.pl/artykul/794384.html, 15.01.2013.

${ }^{34}$ Ibidem.

${ }^{35}$ C. Michalski, TV Trwam na multipleksie, czyli kopanie się z Rydzykiem, http://polska.newsweek.pl/tv-trwam-na-multipleksie — czyli-kopanie-sie-z-rydzykiem,87472,1,1.html, 15.01.2013.

${ }^{36}$ Ibidem.
} 
od 1 stycznia do 19 lutego 2012 r. średnio 5,7 tys. widzów. Liczba odbiorców w znaczącym stopniu odbiegała od widowni takich kanałów jak Polo TV czy Eska TV (wykres 1) ${ }^{37}$.

Wykres 1. Średnia oglądalność minutowa programu

Średnia widownia (AMR) w okresie 1.01-19.02.2012

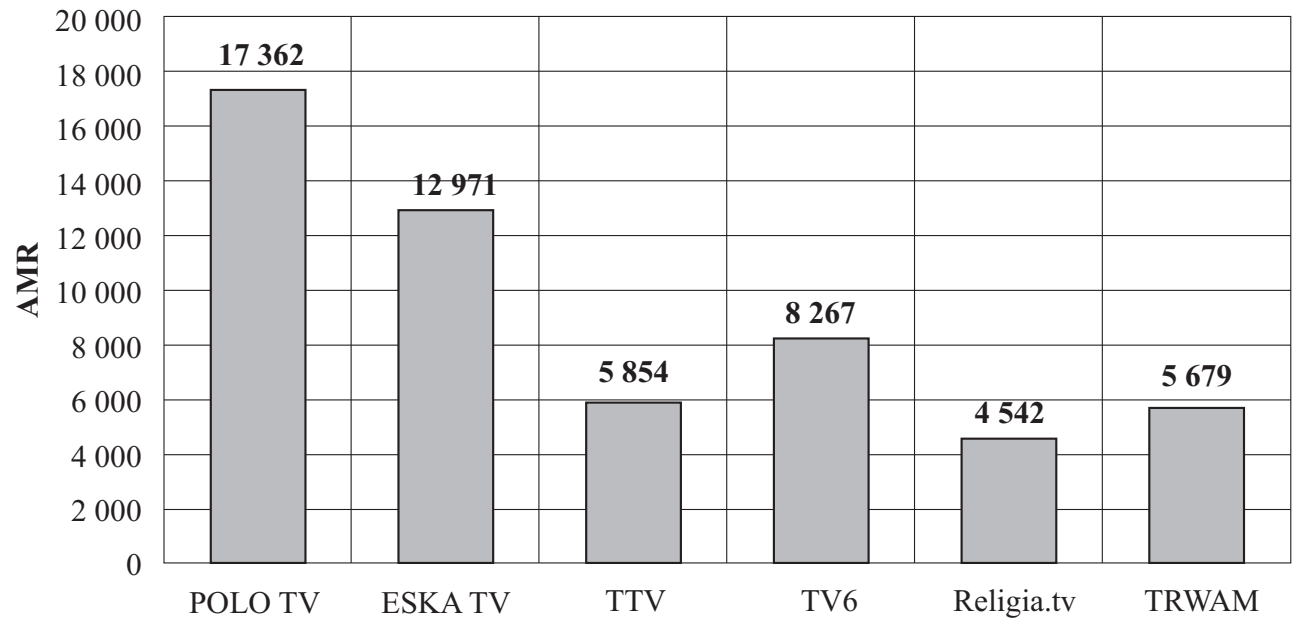

AMR - Average Minute Rating - średnia oglądalność minutowa programu.

Źródło: Krajowa Rada Radiofonii i Telewizji, Widownia programów Polo TV, Eska TV, TTV, TV6 oraz TV Trwam $i$ Religia.tv w okresie: 1 stycznia-19 lutego 2012 r., raport opracowany na podstawie danych Nielsen Audience Measurement, Warszawa, 27 lutego 2012, http://www.krrit.gov.pl/Data/Files/_public/Portals/0/komunikaty/kp2012/sprostowania/raport_mux_1.pdf, 16.01.2013.

Badania pokazały także, że największą oglądalnością z całej ramówki cieszyła się dwudziestominutowa transmisja (godz. 21.00-21.20) Apelu Jasnogórskiego nadawanego z częstochowskiego sanktuarium - 39 tys. widzów (wykres 2).

W spór z KRRiT w sprawie miejsca na multipleksie dla TV Trwam czynnie włączyli się posłowie Prawa i Sprawiedliwości, którzy wielokrotnie wyrażali dezaprobatę wobec decyzji Rady. Ponadto, w styczniu 2012 r. przedstawiciele największej partii opozycyjnej zapowiedzieli przygotowanie wniosku o postawienie członków KRRiT przed Trybunałem Stanu. Elżbieta Kruk, posłanka PiS zasiadająca w sejmowej Komisji Kultury i Środków Przekazu argumentowała podczas jednej z konferencji prasowej, że doszło do łamania i nierealizowania obowiazków konstytucyjnych przez członków Krajowej Rady Radiofonii i Telewizji ${ }^{38}$. Ten radykalny krok powodowany był m.in. sytuacją, która miała miejsce podczas obrad senackiej komisji kultury, podczas której - jak ocenił senator PiS Jan Maria Jackowski - Jan Dworak nie byt w stanie przekonujaco odpowiedzieć na stawiane pytania i lansowat tezę, że Fundacja

\footnotetext{
${ }^{37}$ Krajowa Rada Radiofonii i Telewizji, Widownia programów Polo TV, Eska TV, TTV, TV6 oraz TV Trwam i Religia.tv w okresie: 1 stycznia-19 lutego 2012 r., raport opracowany na podstawie danych Nielsen Audience Measurement, Warszawa, 27 lutego 2012, http://www.krrit.gov.p1/Data/Files/_public/Portals/0/komunikaty/kp2012/sprostowania/raport_mux_1.pdf, 16.01.2013.

${ }^{38}$ Trybunat Stañu dla członków KRRiT?, http://niezalezna.pl/22052-trybunal-stanu-dla-czlonkow-krrit, 16.01.2013.
} 
Wykres 2. Oglądalność TV Trwam w ciągu doby

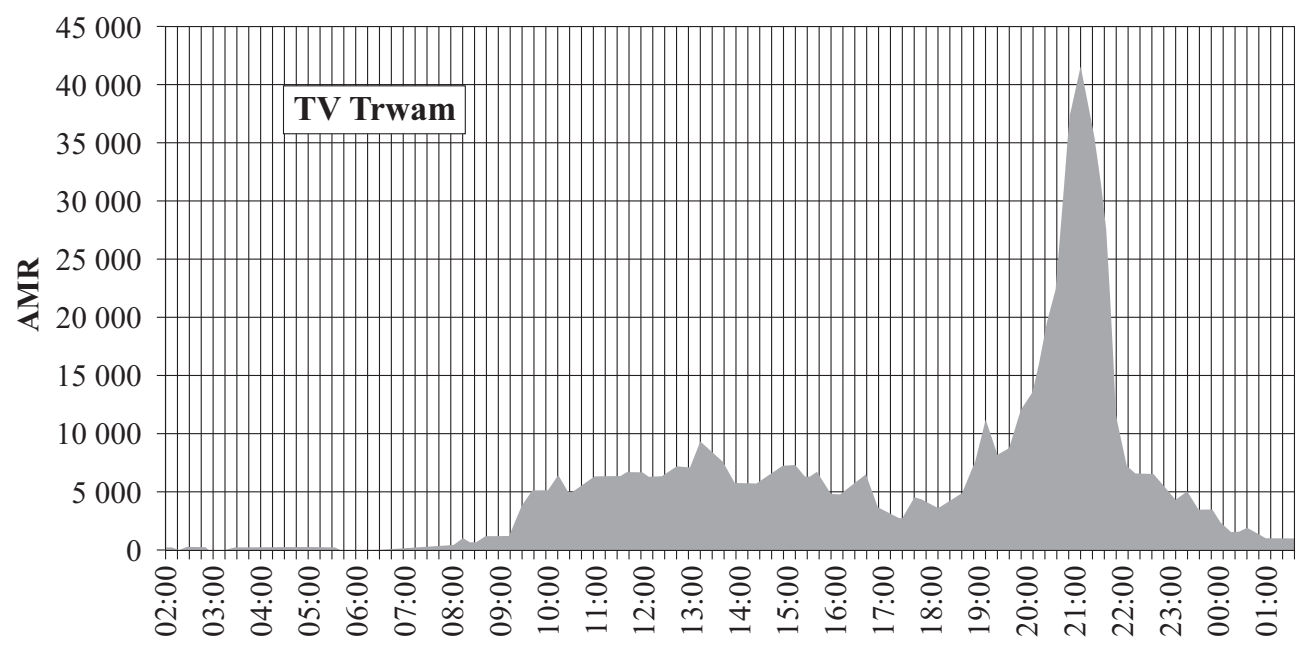

Źródło: Krajowa Rada Radiofonii i Telewizji, Widownia programów Polo TV, Eska TV, TTV, TV6 oraz TV Trwam i Religia.tv w okresie: 1 stycznia-19 lutego 2012 r., raport opracowany na podstawie danych Nielsen Audience Measurement, Warszawa, 27 lutego 2012, http://www.krrit.gov.pl/Data/Files/_public/Portals/0/komunikaty/kp2012/sprostowania/raport_mux_1.pdf, 16.01.2013.

Lux Veritatis ma słabe finansowanie $i$ nie spetnia gwarancji finansowych, aby udźwignać projekt, jakim jest nadawanie cyfrowe ${ }^{39}$. Zapowiadany wniosek został złożony jeszcze w styczniu ${ }^{40}$. Jarosław Kaczyński zwrócił wówczas uwagę, że odmawianie koncesji TV Trwam to skandal i pokazanie, że wolność mediów nie istnieje ${ }^{41}$. Kilka miesięcy później sejmowa Komisja Odpowiedzialności Konstytucyjnej uznała, że wniosek PiS wymaga uzupełnienia braków formalnych. Jedno z takich uchybień dotyczyło np. listy wnioskodawców - pojawił się wykaz posłów popierających wniosek, zaś przepisy i praktyka wymagają, by były to podpisy. We wrześniu 2012 r. wspomniana wyżej komisja uznała wniosek za formalnie poprawy. W myśl zapowiedzi wniosek miał być rozpatrzony przez Sejm do końca 2012 r. Tak się nie stało. Z drugiej strony wydaje się, iż przy obecnym podziale mandatów, koalicja rządząca mogłaby zablokować wniosek.

Oprócz wniosku o Trybunał Stanu dla członków KRRiT, w lutym 2012 r. Fundacja Lux Veritatis zaskarżyła styczniową decyzję Rady do Wojewódzkiego Sądu Administracyjnego w Warszawie ${ }^{42}$. W skardze postulowano przyznanie koncesji cyfrowej dla TV Trwam i wstrzymania nadawania całego multipleksu pierwszego. Ponadto fundacja domagała się, by sąd wyznaczył biegłego, który porównałby sytuację finansową spółek, które otrzymały koncesje i tych, które ich nie dostały. Fundacja po raz kolejny zarzuciła Radzie naruszenie przypisów oraz niedostateczne wyjaśnienie podstaw i przesłanek wydania decyzji ${ }^{43}$.

\footnotetext{
${ }^{39}$ Ibidem.

${ }^{40}$ We wniosku nie wymieniono członka Rady Stefana Pastuszki, który wstrzymał się podczas głosowania nad przyznaniem TV Trwam miejsca na multipleksie cyfrowym. Zob. treść wniosku: http://www.radiomaryja.pl/bez-kategorii/wniosek-do-trybunalu-stanu/, 16.01.2013.

${ }^{41}$ PiS w obronie TV Trwam, http://www.rp.pl/artykul/738666,800204-PiS-zlozylo-wniosek-o-TS-dla-czesci-czlonkow-KRRiT.html, 16.01.2013.

${ }^{42}$ Podobnie - w marcu - uczyniła spółka Mediasat, właściciel kanału Tele5.

${ }^{43}$ Por. Lux Veritatis idzie do sqdu, http://kosciol.wiara.pl/doc/1085844.Lux-Veritatis-idzie-do-sadu, 18.01.2013.
} 
25 maja 2012 r. sąd oddalił w całości skargę fundacji na decyzję KRRiT ${ }^{44}$. Warto jednak odnotować, że sędzia Andrzej Wieczorek - zgłaszając zdanie odrębne do wyroku - podzielił zarzuty fundacji. Stwierdził także, nieważność decyzji KRRiT jako wydanej z rażącym naruszeniem prawa. W uzasadnieniu czytamy m.in.: Udzielenie koncesji na rozpowszechnianie programów radiowych i telewizyjnych jest niewatpliwie sprawa publiczna powinno zatem podlegać regułom rzadzacym działaniami o charakterze publicznym. Należa do nich m.in. jawność podejmowania decyzji i równe traktowanie wszystkich zainteresowanych, dajace im równe szanse w ubieganiu się o dobra reglamentowane ${ }^{45}$. Zdaniem sędziego trzy podmioty, które uzyskały koncesję nie dostarczyły wymaganych dokumentów - jedna ze spółek przedstawiła np. opinię bankową wskazującą obroty na rachunku za ostanie trzy miesiące, a zgodnie z rozporządzeniem Rady należało przedstawić taką opinię za cały rok. Sędzia A. Wieczorek uznał, że Lux Veritatis dysponuje wystarczającymi wpływami, które gwarantowałyby powodzenia przedsięwzięcia. Zakładając nawet tendencję spadkowa, bazując na wskaźnikach z lat 2008-2010 i tak można przewidywać, że wptywy będa na poziomie przekraczajacym dwu jak $i$ nie trzykrotnie zakładane wpływy ${ }^{46}$ - tłumaczył sędzia.

24 sierpnia 2012 r. Fundacja Lux Veritatis złożyła do Naczelnego Sądu Administracyjnego skargę kasacyjną do wyroku Wojewódzkiego Sądu Administracyjnego w Warszawie. Fundacja wniosła o uchylenie wyroku sądu w całości, wstrzymanie przez NSA decyzji KRRiT o przydziale koncesji na multipleksie pierwszym do czasu rozpatrzenia skargi kasacyjnej. We wniosku postulowano szybkie rozpoznanie sprawy ze względu na jej szeroki oddźwięk społeczny i potrzebę utrzymania zaufania społecznego do władzy publicznej ${ }^{47}$.

W międzyczasie (lipiec 2012 r.) upubliczniony został raport Najwyższej Izby Kontroli, w którym zarzucono KRRiT rażące błędy w postępowaniu koncesyjnym. Zwrócono bowiem uwagę, że nadawcy, którzy otrzymali koncesję na MUX-1 byli zdaniem Rady w lepszej sytuacji finansowej niż Lux Veritatis. Po otrzymaniu koncesji okazało się, że podmiotów tych nie stać na opłaty koncesyjne, a Rada zgodziła się je rozłożyć na raty. NIK zarzuciła KRRiT działanie narażające na straty budżet państwa. J. Dworak odpierając stawiane Radzie zarzuty argumentował, że rozkładanie opłat koncesyjnych na raty nie jest naruszeniem prawa, a powszechnie stosowaną praktyką ${ }^{48}$.

Po ujawnieniu tych informacji PiS i Solidarna Polska zażądały dalszych kontroli procesu koncesyjnego, zaś Fundacja Lux Veritatis złożyła do prokuratury zawiadomienie o podejrzeniu popełnienia przestępstwa w zawiązku z decyzją KRRiT. W doniesieniu zwrócono uwagę, że osoby działające w imieniu podmiotów, które otrzymały koncesję mogły poświadczyć nieprawdę, a przewodniczący, członkowie i pracownicy KRRiT mogli poświadczyć nieprawdę lub niedopełnić obowiązków ${ }^{49}$. Prokuratura odmówiła jednak postępowania w tej sprawie tłumacząc m.in., że nie jest organem, który ma badać orzeczenia wydawane przez organa administracyjne.

44 Wyrok Wojewódzkiego Sądu Administracyjnego w Warszawie z dnia 25 maja 2012 r., sygn. akt. VI SA/Wa $627 / 12$.

${ }^{45}$ http://www.krrit.gov.pl/Data/Files/_public/Portals/0/radiofonia\%20i\%20telewizja\%20cyfrowa/zdanie-odrebne-a.wieczorka.pdf, 20.01.2013.

${ }^{46}$ Ibidem.

${ }^{47}$ M. Goss, Jest kasacja, http://www.naszdziennik.pl/polska-kraj/8174,jest-kasacja.html, 21.01.2013.

${ }^{48}$ K. Baranowska, I. Kacprzak, NIK uratuje o. Rydzyka?, http://www.rp.pl/artykul/118849,908467-NIK-ura- tuje-o-Rydzyka-.html, 21.01.2013.

${ }^{49}$ Lux Veritatis skarży opłaty za multipleks, http://www.rp.pl/artykul/118849,915885-Lux-Veritatis-skarzy-oplaty-za-multipleks.html, 21.01.2013. 
W pejzaż sporu o multipleks dla TV Trwam w 2012 r. wkomponowały się ogólnopolskie wiece, manifestacje i marsze w obronie wolnych mediów - w tym telewizji i Radia Maryja. Miały one jednak charakter polityczny, antyrządowy. Wielokrotnie skandowano bowiem hasła wzywające do usunięcia rządu Donalda Tuska. W jednym z marszy zorganizowanym 29 września 2012 r. w Warszawie pod nazwą „Obudź się Polsko” wzięło udział - według danych organizatorów - ok. 180 tys. ludzi, zaś zdaniem służb zabezpieczających zgromadzenie - ok. 50 tys. osób. Marsz był wiecem politycznym, podczas którego głos zabrali m.in. Jarosław Kaczyński i przewodniczący NSZZ „Solidarność” Piotr Duda.

\section{Druga szansa TV Trwam}

W grudniu 2012 r. przewodniczący KRRiT ogłosił konkurs na ostatnie cztery miejsca na multipleksie pierwszym. Rada zdecydowała, że znajdą się na nim cztery programy:

- program społeczno-religijny - zawierający transmisje i relacje z nabożeństw i uroczystości religijnych, wydarzeń z życia Kościoła i społeczeństwa, edukujący w zakresie historii i współczesności chrześcijaństwa w duchu nauczania Stolicy Apostolskiej i jedności z Episkopatem Polski. Audycje poświęcone tematyce religijnej będą propagowały tolerancję i treści ekumeniczne oraz działania w duchu dialogu międzyreligijnego. Audycje realizujące specjalizację będą wskazywać wartości, wspierać rozwój człowiek i rodziny w wolnym demokratycznym społeczeństwie ${ }^{50}$;

- program edukacyjno-poznawczy - prezentujący filmy, reportaże oraz inne audycje z takich dziedzin jak: nowe technologie i wynalazki, gospodarka, kultura i historia cywilizacji świata oraz o tematyce podróżniczej, etnograficznej, przyrodniczej i ekologicznej ${ }^{51}$;

— program filmowy - prezentujący głownie polskie lub różnorodne filmy kina światowego: fabularne, dokumentalne, animowane. Program zawierać będzie także inne audycje poświęcone współczesnej kinematografii oraz historii kina polskiego i światowego (sylwetki twórców, relacje z festiwali i inne), a także audycje z zakresu edukacji filmowej i medialnej ${ }^{52}$;

— program dla dzieci w wieku 4-12 lat oraz ich rodziców i wychowawców - prezentujący różne rodzaje audycji (m.in. bajki, przedstawienia teatralne, audycje edukacyjne, filmy: fabularne, animowane, dokumentalne), ułatwiający poznanie świata, wspomagający wszechstronny rozwój tej grupy odbiorców, a także wskazujący wzorce i wspierający opiekunów w rozwiązywaniu problemów wychowawczych. Program będzie zawierał audycje poradnikowe i edukacyjne (m.in. nauka języków obcych) ${ }^{53}$.

Roczne koszty nadawania na multipleksie Rada szacuje na ok. 7 mln zł. Nadawca musi także ponieść koszty związane z produkcją programu oraz wnieść opłatę za udzielenie dziesięcioletniej koncesji - do $12 \mathrm{mln} 945$ tys.

\footnotetext{
${ }^{50}$ Ogłoszenie Przewodniczącego Krajowej Rady Radiofonii i Telewizji z dnia 20 grudnia 2012 r. o możliwości uzyskania koncesji na rozpowszechnianie programu telewizyjnego (M.P. 2012, poz. 1014).

${ }^{51}$ Ogłoszenie Przewodniczącego Krajowej Rady Radiofonii i Telewizji z dnia 20 grudnia 2012 r. o możliwości uzyskania koncesji na rozpowszechnianie programu telewizyjnego (M.P. 2012, poz. 1015).

${ }^{52}$ Ogłoszenie Przewodniczącego Krajowej Rady Radiofonii i Telewizji z dnia 20 grudnia 2012 r. o możliwości uzyskania koncesji na rozpowszechnianie programu telewizyjnego (M.P. 2012, poz. 1016).

${ }^{53}$ Ogłoszenie Przewodniczącego Krajowej Rady Radiofonii i Telewizji z dnia 20 grudnia 2012 r. o możliwości uzyskania koncesji na rozpowszechnianie programu telewizyjnego (M.P. 2012, poz. 1017).
} 
Szybko po ogłoszeniu konkursu pojawiły się doniesienia, iż prowadzone są rozmowy, by zamiast TV Trwam, miejsce na MUX-1 otrzymała inna stacja o charakterze społeczno-religijnym $^{54}$. Komunikat w tej sprawie wydał o. T. Rydzyk podejrzewający, że konkurs jest ,ustawiony". W sposób mogący budzić kontrowersje napisał: Z komunikatów KRRiT wynika, że zapadła decyzja, żeby nie dać TV Trwam miejsca na multipleksie. Nie będę mówił, które z tych wypowiedzi wskazuje na taki wniosek. Jest to bardzo wyraźne, w planach jest inna telewizja. Już raz tak było; żeby wprowadzić w bład ludzi. ITI już raz stworzyła taka telewizję. Ten koncern jest posiadaczem m.in. TVN. Wiemy, że nie jest to koncern ewangelizacyjny; wiemy ile zła wyrzadził Kościołowi i Ojczyźnie. Dzieli on Polaków przez działania antypatriotyczne $i$ antykościelne, antykatolickie, to jest bardzo wyraźne. Wiemy ile zła ten koncern wyrzadzit odbierajac nam dobre imię. Niejednokrotnie wpisywat się $w$ te media, które odbieraty dobre imię Radiu Maryja i dziełom przy nim powstałym. Pamiętam także, jak w wypowiedziach odbierali nam dobre imię. Czy taki podmiot może ewangelizować? Pamiętamy, że to oni wtaśnie stworzyli kanat Religia.t ${ }^{55}$. Jan Dworak w rozmowie z dziennikiem ,Rzeczpospolita” powiedział, że wypowiedzi o. Rydzyka nie sq oparte na żadnych podstawach ${ }^{56}$.

Głos w sprawie zabrał na początku stycznie 2013 r. abp Leszek Sławoj Głódź, delegat Konferencji Episkopatu Polski ds. TV Trwam, który w rozmowie z Katolicką Agencją Informacyjną zaapelował, by KRRiT jednoznacznie przedstawiła swoje stanowisko w sprawie konkursu na miejsce na multipleksie pierwszych i TV Trwam ${ }^{57}$. Słowa hierarchy należy jednak traktować z dystansem, gdyż może to tworzyć niebezpieczną sytuację, w której KRRiT jeszcze przed rozstrzygnięciem konkursu ogłosiłaby swoją decyzję o przyznaniu (bądź nie) TV Trwam miejsca na MUX-1.

Przewodniczący KRRiT w odpowiedzi na zarzuty ze strony oponentów wyraził pogląd, że stawiane Radzie zarzuty o „ustawienie” konkursu ocieraja się o granicę pomówienia. W tym kontekście J. Dworak odniósł się także do artykułów, które ukazały się na łamach „Naszego Dziennika" o - można powiedzieć - mocno sugestywnych tytułach: Koalicja przeciw Trwam $^{58}$ i Konkurs z ustawka ${ }^{59}$, przewodniczący zapowiedział możliwość podjęcia kroków prawnych w tej sprawie ${ }^{60}$.

Kolejną odsłoną spory był wniosek klubu parlamentarnego PiS o zwołanie specjalnego posiedzenia sejmowej Komisji Administracji i Cyfryzacji z udziałem ministra Michała Boniego i członków KRRiT. Spotkanie takie odbyło się 7 lutego 2013 r. i zakończyło się awantura. Przedstawiciele Rady - Jan Dworak, Witold Graboś i Krzysztof Luft wyszli z posiedzenia komisji uznając, że zadawane im przez posłów pytania (w obecności zaproszonego na posiedzenie komisji o. T. Rydzyka) dotyczyły tylko TV Trwam, co ingerowało w proces

\footnotetext{
${ }^{54}$ Chodzi o program Religia.tv, choć konkurencją może okazać się także Boska.tv. W przypadku pierwszego wymienionego kanał wątpliwości rozwiał ks. Kazimierz Sowa zaprzeczają, iż program będzie ubiegał się o miejsce na multipleksie. Nie mamy ani takich zamiarów, ani pieniędzy - powiedział w jednym z wywiadów.

${ }_{55}$ O. Rydzyk: Nadal toczy się walka o Telewizje Trwam!, http://www.niedziela.pl/artykul/3614/O-Rydzyk-Nadal-toczy-sie-walka-o, 12.02.2013.

${ }^{56}$ J. Stróżyk, K. Baranowska, Wojna o religijna koncesję, http://www.rp.pl/artykul/793961,965632-Wojna-o-religijna-koncesje.html, 12.02.2013.

${ }_{57}$ Niech KRRiT wyraża sie precyzyjnie ws. TV Trwam, http://ekai.pl/wydarzenia/komentarze/x62212/niech-krrit-wyraza-sie-precyzyjnie-ws-tv-trwam/, 3.01.2013.

${ }^{58}$ Koalicja przeciw Trwam, z o. T. Rydzykiem rozmawia Krzysztof Losz, „Nasz Dziennik” z 31 grudnia 2012 r. - 1 stycznia $2013 \mathrm{r}$.

${ }^{59}$ K. Losz, Konkurs z ustawkq, „Nasz Dziennik” z 28 grudnia 2012 r.

${ }^{60}$ KRRiT: media o. Rydzyka przekroczyly granice pomówienia, http://www.rp.pl/artykul/793961,965962-KRRiT-chce-oskarzyc-media-o_Rydzyka-o-pomowienie.html, 15.02.2013.
} 
koncesyjny i dyskredytowało potencjalnych konkurentów. Przed opuszczeniem sali W. Graboś powiedział, że pomimo życzliwości wobec Fundacji Lux Veritatis, musi opuścić posiedzenie, gdyż nie chce się narazić na zarzut, iż jest stronniczy. Przebieg posiedzenia komisji ingeruje już w niezależność organu i bezstronność przeprowadzanego konkursu ${ }^{61}$ - dodał Jan Dworak.

W ostatnich dniach lutego 2013 r. w mediach pojawiły się informacje, że J. Dworak i członek rady Krzysztof Luft otrzymali list, w którym były groźby wyroku śmierci i hasło „śmierć wrogom ojczyzny”. Jeśli Telewizja Trwam tej licencji nie dostanie do marca, nasz pluton egzekucyjny dostanie polecenie wyeliminować zdrajców ${ }^{62}$ - ujawniła treść listu z pogróżkami „Gazeta Wyborcza”.

\section{Podsumowanie}

26 lutego 2013 r. KRRiT poinformowała w komunikacie prasowym, że do dnia 25 lutego wpłynęło 12 wniosków koncesyjnych w konkursie na cztery ostanie miejsca na multipleksie naziemnej telewizji cyfrowej. Liczba wniosków może się jeszcze zmienić, gdyż oferty można było nadsyłać listownie. W momencie ukończenia niniejszego tekstu (koniec lutego 2013 r.) KRRiT nie poinformowała jakie podmioty zgłosiły wnioski. Z doniesień prasowych wiadomo jednak, że w konkursie wystartuje Fundacja Lux Veritais, a jednym z jej konkurentów w zakresie programu społeczno-religijnego będzie Platforma Mediowa Point Group, wydawca tygodników „Wprost” i „Do Rzeczy”63. Trudno jednoznacznie odpowiedzieć na pytanie czy TV Trwam ostatecznie uzyska miejsce na MUX-1. Jeśli nie, można spodziewać się zaostrzenia sporu, kolejnych zarzutów o dyskryminację katolików, katolickich mediów, Kościoła i następnych kroków prawnych ze strony Fundacji Lux Veritatis. Warto także mieć na uwadze, iż na ostateczne rozstrzygnięcie czeka wniosek kasacyjny dotyczący unieważnienia decyzji KRRiT z 2011 r. złożony w Naczelnym Sądzie Administracyjnym. W dalszym ciąu nie został rozpoznany przez Sejm wniosek opozycji o postawienie czterech członków Rady przed Trybunałem Stanu. Interesującym wydaje się również pytanie, jak będą wyglądały relacje pomiędzy KRRiT a jej obecnymi oponentami, w sytuacji gdy Rada jednak przyzna telewizji miejsce na multipleksie.

Niewątpliwie trwający od wielu miesięcy spór przyjmował coraz ostrzejszą formę, w której nie brakowało wzajemnych oskarżeń o nieuczciwość, dyskryminację, niszczenie Polski i Kościoła. Spór ten przybrał niebezpieczny charakter polityczny. Warto w tym kontekście przypomnieć, że żadna partia polityczna w swojej działalności nie powinna angażować autorytetu Kościoła, a i Kościół powinien z rozwagą podchodzić do polityki i być autonomiczny wobec porządku politycznego, społecznego czy gospodarczego. Wśród wielu komentarzy w tej sprawie, jeden wybrzmiał szczególnie mocno i dosadnie, tym bardziej, że słowa te płyną z wnętrza Kościoła. W lutym 2013 r. na łamach „Tygodnika Powszechnego” ukazał się obszerny artykuł o. Ludwika Wiśniewskiego, w którym napisał m.in. Od wielu miesięcy trwa w polskim Kościele swoisty ,, festiwal” pod hasłem ,, szukaj wroga”. Ten ,,festiwal” reżyserowany przez o. Tadeusza Rydzyka i przeradzajacy się chwilami w żałosny kabaret, objat swoim zasieggiem tysiqce, a nawet miliony ludzi: zawojowat pocztę, rozsiat się $w$ kruchtach koś-

\footnotetext{
${ }^{61}$ S. Kucharski, KRRiT wychodzi, bo PiS lobbuje za TV Trwam, „Gazeta Wyborcza” z 8 lutego 2013 r.

${ }^{62}$ Idem, Kto grozi śmierciq KRRiT, „Gazeta Wyborcza” z 22 lutego 2013 r.

${ }^{63}$ M. Goss, Kto na multipleks?, „Nasz Dziennik” z dnia 27 lutego 2013 r.
} 
ciołów, wyptynat na ulice, porwat w swój wir wielu biskupów, dotart nawet do Rzymu, aby ostatecznie zamknqć usta przeciwnikom. Jesteśmy świadkami jakiegoś zbiorowego szaleństwa, któremu nadaje się nazwe „,przebudzenie”. To niby przebudzenie uderza nie tylko w porzqdek prawny naszego państwa, ale także w Kościót. [...] Marsze w obronie TV Trwam sq nazywane przez niektórych biskupów , lekcjami patriotyzmu” $i$, lekcjami miłości Ojczyzny”. W istocie sq to lekcje, jak niszczyć Ojczyznę i Kościót ${ }^{64}$.

\section{Bibliografia}

Apel Rady Stałej KEP w sprawie TV Trwam, Redemptor.pl, 17.01.2012, http://www.redemptor.pl/aktualnosci.php?id=339\&typ=1.

Baranowska K., Kacprzak I., NIK uratuje o. Rydzyka?, ,Rzeczpospolita”, 5.07.2012, http://www.rp.pl/artykul/118849,908467-NIK-uratuje-o-Rydzyka-.html.

Dworak: nie ma żadnego spisku, „Rzeczpospolita”, 21.04.2012, http://www.rp.pl/artykul/793961,864022-Dworak-nie-ma-spisku-majacego-na-celu-likwidacje-TV-Trwam.html.

Dytkowski J., Złe rozdanie Dworaka, „Nasz Dziennik”, 25.08.2012, http://stary.naszdziennik.pl/index.php?dat=20110825\&typ=po\&id=po03.txt.

Fundacja Lux Veritatis, http://luxveritatis.pl.

Goss M., Jest kasacja, „Nasz Dziennik”, 25.08.2012, http://www.naszdziennik.p1/polska-kraj/8174,jest-kasacja.html.

Goss M., Kto na multipleks?, „Nasz Dziennik” z 27 lutego 2013 r.

Kacprzak I., Baranowska K., Wybranowski W., TV Trwam finansowo stoi lepiej niż inni nadawcy, 19.01.2012, http://www.rp.pl/artykul/794384.html.

Koalicja przeciw Trwam, z o. T. Rydzykiem rozmawia Krzysztof Losz, „Nasz Dziennik” z dnia 31 grudnia 2012 r. -1 stycznia $2013 \mathrm{r}$.

Komunikat prasowy, KRRiT utrzymała w mocy decyzję Przewodniczqcego z 29 lipca 2011 r. o rozszerzeniu koncesji na nadawanie satelitarne naziemne w sygnale multipleksu pierwszego, Krajowa Rada Radiofonii i Telewizji, 17.01.2012, http://www.krrit.gov.pl/dla-mediow-i-analitykow/aktualnosci/news,576, krrit-utrzymala-w-mocy-decyzje-przewodniczacego-z-29-lipca-2011-r-o-rozszerzeniu-koncesji-na-nadawanie-satelitarne-naziemne-w-sygnale-multipleksu-pierwszego.html.

Komunikat prasowy, MUX-1 i cyfryzacja telewizji w Polsce, Krajowa Rada Radiofonii i Telewizji, 21.04.2012, http://www.krrit.gov.pl/dla-mediow-i-analitykow/aktualnosci/news, 648 , mux-1-i-cyfryzacja-telewizji-w-polsce--konferencja-prasowa-krrit.html.

Krajowa Rada Radiofonii i Telewizji, http://www.krrit.gov.pl.

Krajowa Rada Radiofonii i Telewizji, Widownia programów Polo TV, Eska TV, TTV, TV6 oraz TV Trwam i Religia.tv w okresie: 1 stycznia - 19 lutego 2012 r., Raport opracowany na podstawie danych Nielsen Audience Measurement, http://www.krrit.gov.pl/Data/Files/_public/Portals/0/komunikaty/kp2012/sprostowania/raport_mux_1.pdf, Warszawa 2012.

KRRiT: media o. Rydzyka przekroczyly granice pomówienia, „Rzeczpospolita”, 2.01.2013, http://www.rp.pl/artykul/793961,965962-KRRiT-chce-oskarzyc-media-o-Rydzyka-o-pomowienie.html.

Kucharski S., KRRiT wychodzi, bo PiS lobbuje za TV Trwam, „Gazeta Wyborcza” z dnia 8 lutego 2013 r.

Kucharski S., Kto grozi śmierciq KRRiT, „Gazeta Wyborcza” z dnia 22 lutego 2013 r.

Losz K., Konkurs z ustawka, „Nasz Dziennik” z dnia 28 grudnia 2012 r.

Lux Veritatis idzie do sqdu, Wiara.pl, 21.02.2012, http://kosciol.wiara.pl/doc/1085844.Lux-Veritatis-idzie-do-sadu.

Lux Veritatis skarży opłaty za multipleks, „Rzeczpospolita”, 19.07.2012, http://www.rp.pl/artykul/118849,915885-Lux-Veritatis-skarzy-oplaty-za-multipleks.html.

Media dawne $i$ wspótczesne, red. B. Kosmanowa, t. III, Wydawnictwo Naukowe WNPiD UAM, Poznań 2008.

Media dawne $i$ wspótczesne, red. B. Kosmanowa, t. V, Wydawnictwo Naukowe WNPiD UAM, Poznań 2010.

${ }^{64}$ L. Wiśniewski, Gdzie jesteśmy?, „Tygodnik Powszechny” 2013, nr 9. 
Michalski C., TV Trwam na multipleksie, czyli kopanie się z Rydzykiem, „Newsweek”, 23.01.2012, http://polska.newsweek.pl/tv-trwam-na-multipleksie_czyli-kopanie-sie-z-rydzykiem,87472,1,1.html.

Ministerstwo Administracji i Cyfryzacji, http://www.cyfryzacja.gov.pl.

Narodowy Fundusz Ochrony Środowiska i Gospodarki Wodnej, http://www.nfosigw.gov.pl.

Niech KRRiT wyraża się precyzyjnie ws. TV Trwam, eKai.pl, 3.01.2013, http://ekai.pl/wydarzenia/komenta$\mathrm{rze} / \mathrm{x} 62212 /$ niech-krrit-wyraza-sie-precyzyjnie-ws-tv-trwam/.

O. Rydzyk: Nadal toczy się walka o Telewizję Trwam!, „Niedziela”, http://www.niedziela.pl/artykul/3614/O-Rydzyk-Nadal-toczy-sie-walka-o.

Ogłoszenie Przewodniczącego Krajowej Rady Radiofonii i Telewizji z dnia 20 grudnia 2012 r. o możliwości uzyskania koncesji na rozpowszechnianie programu telewizyjnego, M.P. 2012, poz. 1014.

Ogłoszenie Przewodniczącego Krajowej Rady Radiofonii i Telewizji z dnia 20 grudnia 2012 r. o możliwości uzyskania koncesji na rozpowszechnianie programu telewizyjnego, M.P. 2012, poz. 1015.

Ogłoszenie Przewodniczącego Krajowej Rady Radiofonii i Telewizji z dnia 20 grudnia 2012 r. o możliwości uzyskania koncesji na rozpowszechnianie programu telewizyjnego, M.P. 2012, poz. 1016.

Ogłoszenie Przewodniczącego Krajowej Rady Radiofonii i Telewizji z dnia 20 grudnia 2012 r. o możliwości uzyskania koncesji na rozpowszechnianie programu telewizyjnego, M.P. 2012, poz. 1017.

PiS w obronie TV Trwam, „Rzeczpospolita”, 30.01.2012, http://www.rp.pl/artykul/738666,800204-PiS-zlozylo-wniosek-o-TS-dla-czesci-czlonkow-KRRiT.html.

Przewodniczący Krajowej Rady Radiofonii i Telewizji, Decyzja Nr DK - 137/2011 z 29 lipca 2011 r.

Radio Maryja, http://www.radiomaryja.pl.

Secler B., Dwie dekady katolickich środków spolecznego przekazu w Polsce (1989-2009), w: Media dawne $i$ współczesne, red. B. Kosmanowa, t. V, Wydawnictwo Naukowe WNPiD UAM, Poznań 2010.

Secler B., Wolność katolickich środków społecznego przekazu. Rzeczywistość czy fikcja?, w: Media dawne $i$ współczesne, red. B. Kosmanowa, t. III, Wydawnictwo Naukowe WNPiD UAM, Poznań 2008.

Skrzypczak J., Polityka medialna $w$ okresie konwersji cyfrowej radiofonii i telewizji, Wydawnictwo Naukowe WNPiD UAM, Poznań 2011.

Stróżyk J., Baranowska K., Wojna o religijna koncesję, „Rzeczpospolita”, 2.01.2013, http://www.rp.pl/artykul/793961,965632-Wojna-o-religijna-koncesje.html.

Trybunat Stanu dla członków KRRiT?, Niezależna.pl, 19.01.2012, http://niezalezna.pl/22052-trybunal-stanu-dlaczlonkow-krrit.

Ustawa z dnia 16 lipca 2004 r. - Prawo telekomunikacyjne, Dz. U. 2004, Nr 171, poz. 1800 z późn. zm. Ustawa z dnia 30 czerwca 2011 r. o wdrożeniu naziemnej telewizji cyfrowej, Dz. U. 2011, Nr 153, poz. 903.

Wiśniewska K, Kopiński M., Hołub J., Już dość Rydzyka, „Gazeta Wyborcza” z dnia 16 lutego 2006 r.

Wiśniewski L., Gdzie jesteśmy?, „Tygodnik Powszechny” 2013, nr 9.

Wyrok Wojewódzkiego Sądu Administracyjnego w Warszawie z dnia 25 maja 2012 r., sygn. akt. VI SA/Wa 627/12.

Zieliński Z., Kościól w Polsce 1944-2007, Wydawnictwo Poznańskie, Poznań 2009.

\section{The multiplex dispute. Telewizja Trwam vs. the National Broadcasting Council}

\section{Summary}

The digitalization of terrestrial television in Poland is one of the largest media projects in recent years. The process combines social, economic and technical matters. Digitalization signifies a huge technical leap forward and offers extensive new opportunities when broadcasting television signals. Digital broadcasting is offered by three multiplex platforms. Among the candidates to use the first one (MUC-1) is Telewizja Trwam, owned by the Lux Veritatis foundation. The National Broadcasting Council (KRRiT) which assigns the concessions to use the multiplex rejected the application by Telewizja Trwam, associated with Fr. Tadeusz Rydzyk. The owner of Telewizja Trwam claimed the decisions of the KRRiT were baseless. 
There quickly emerged accusations of discrimination against a Catholic broadcaster, and, by this token, of scorn directed toward Polish Catholics. The dispute between Telewizja Trwam and the KRRiT has involved many groups and individuals - ranging from the supporters of the media associated with Fr T. Rydzyk, to journalists, politicians, and to the hierarchy of the Catholic Church in Poland.

The purpose of this paper is to present this dispute, its background and the arguments of both parties. As the dispute was still unresolved when this paper was completed (in late February 2013), the author tried to suggest possible scenarios for its outcome and to draw conclusions for the future. 